\title{
Stress Analysis of Integrated 12.7 mm Machine Gun Mount
}

\author{
Aleksandar Kari ${ }^{1)}$ \\ Dušan Jovanović ${ }^{1)}$ \\ Damir Jerkovic ${ }^{1)}$ \\ Nebojša Hristov ${ }^{1)}$
}

\begin{abstract}
The paper describes the problem of integration $\mathbf{1 2 . 7}$ millimeters machine gun on the mobile platform. Based on the dimensions of the machine gun modeling of machine guns mount with cradle is done. The completed model is fully functional and realistic. Using optimized internal ballistic parameters the calculations of recoil forces and loading of mount and rotating bearing are executed. The loading calculation of bearing was made in two ways. In the first case finite element method is applied and software package FEMAP was used. The second method is based on calculating the resistance components of bearing from the equilibrium condition. At the end the comparative analysis of data obtained from these two methods was done.
\end{abstract}

Key words: machine gun, caliber $12.7 \mathrm{~mm}$, recoil force, stand, bearings, load calculations, stress analysis, finite element analysis, integrated weapon.

\section{Introduction}

$\mathrm{T}$ HE resistance of weapon and its firing stability depends on the value of recoil forces [1]. In the case of the integration of weapons, if the barrel is rigidly connected to the mount, the recoil force is fully transmitted to the mount. In order to avoid inconveniences of such connections, or extended firing time load mount and to reduce its intensity, barrel is elastically connected to the mount which enables the movement of the barrel or whole weapon during firing in the direction of the axis of the barrel.

The study of conditions to be satisfied by the stand of the machine gun to be installed on a mobile platform is the main goal of this paper. This involved the construction of the rotating mount that could withstand the loads created by recoil force, as well as calculation of the forces that are transmitted on the mobile platform. As an example, for the integration was selected machine gun $12.7 \mathrm{~mm} \mathrm{M87.}$

In order to reach the optimal solution, the conditions of the minimal force and minimal recoil mass of the mount are set, taking into account the boundary allowable conditions of material's resistance, as well as, the conditions concerning tactical use. The research was carried out through four main phases:1) Optimization of internal ballistic parameters and their influence on the recoil force of the machine gun; 2) Determination of machine gun recoil force; 3) Designing the appropriate mount based on the construction of the machine gun; 4) Determination of the mount and bearing loading.

The goal is to minimize the pressure of powder gases in the barrel, but with as less as possible reduction of characteristics that affect the efficiency of weapons, primarily projectile velocity at the muzzle, and the required tactical and technical characteristics of the machine guns presented in Table 1 [2].
Table 1. Tactical - technical characteristics of machine gun M87

\begin{tabular}{|c|c||}
\hline Characteristic & Value \\
\hline \hline Caliber, $d$ & $12,7 \times 108 \mathrm{~mm}$ \\
\hline Barrel length, $l$ & $1100 \mathrm{~mm}$ \\
\hline Total length of machine guns, $L$ & $1560 \mathrm{~mm}$ \\
\hline Weight of machine guns, $m$ & $24,8 \mathrm{~kg}$ \\
\hline Rate of fire, $n$ & $700 \mathrm{bullet} / \mathrm{min}$. \\
\hline Effective range, $D_{\max }$ & $1500 \mathrm{~m}$ \\
\hline
\end{tabular}

\section{Recoil force}

For the selection the most rational construction of mount, it is necessary to define the acting forces on the mount as a whole, but also on its individual parts. In the process of firing of the machine gun, force of powder gases is acting on the bolt. After unlocking, the force of the return spring that opposes the force of the pressure powder gases acts on the bolt.

If the machine gun is on the mount and there is an elastic connection between the gun and the mount, there is the resistive force of recoil (force of shock absorber, buffer, hydraulic brake, etc.). There is also a frictional force on the guide rails of machine guns which opposes to the movement of a machine gun during recoil.

Finally, the total recoil force is:

$$
\overrightarrow{P_{k n}}=\overrightarrow{F_{b g}}+\overrightarrow{F_{o p}}+\overrightarrow{F_{b f}}+\overrightarrow{F_{t r}}
$$

where: $F_{b g}$ - force of gas pressure, $F_{o p}$ - force of spring, $F_{b f}$ force of buffer and $F_{t r}$ - frictional force.

Activity of these forces is shown in Fig.1.

\footnotetext{
1) University of Defence, Military Academy, Generala Pavla Jurišića Šturma 33,11000 Belgrade, SERBIA

Correspondence to: Aleksandar Kari; e-mail: aleksandarkari@gmail.com
} 


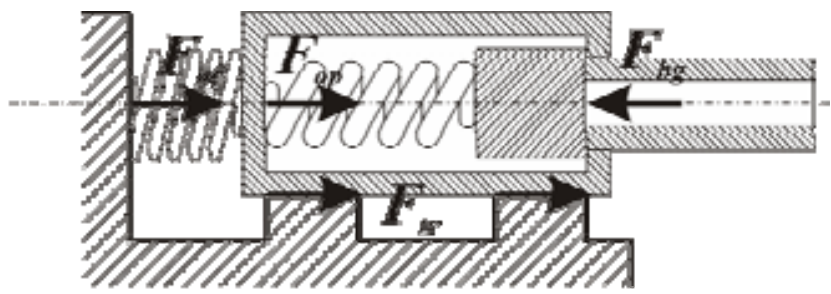

Figure 1. The forces acting on the weapon

The listed forces are parallel to the axis of the barrel, so that the intensity of the total recoil force can be expressed as:

$$
P_{k n}\left(x_{1}, x_{2}, t\right)=F_{b g}(t)-F_{o p}\left(x_{1}\right)-F_{b f}\left(x_{2}\right)-F_{t r}\left(x_{2}\right)
$$

where: $t$ - time from the start firing, $x_{1}$ - movement of bolt and $x_{2}-$ movement of machine gun during recoil.

Some forces were calculated by applying the mathematical, mechanical and ballistic methods, while others are measured on real model of the machine guns.

By internal ballistic calculation [3] the obtained maximum pressure in the barrel of machine guns $12,7 \mathrm{~mm} \mathrm{M} 87$ is $p_{m}=$ 328,98 $\mathrm{MPa}$.

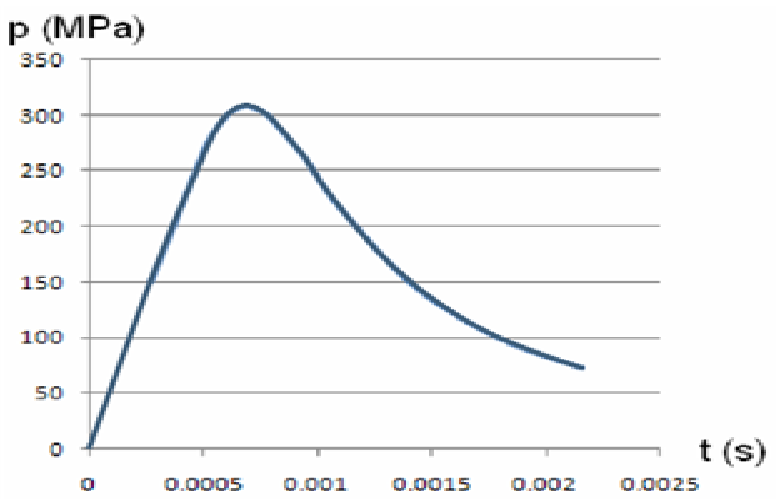

Figure 2. The optimal internal ballistic curve of pressure in the barrel

From a total of 15 parameters that are written in the input file to the internal ballistic calculation the three basic ballistic characteristics of gunpowder are varied: co-volume of powder gases, the specific energy of powder gases and unit burning rate of gunpowder.

The parameters are changed so that the case of incomplete combustion of gunpowder is avoided [4]. By varying these parameters within the range of $\pm 10 \%$ and by selecting the optimum value thereof, reduced the maximum pressure in the barrel $p_{m}=308.25 \mathrm{MPa}$, which represents a reduction of the maximum pressure in the barrel of $6.3 \%$ (Fig.2). The calculated velocity of the projectile at the muzzle is $V_{0}=841$ $\mathrm{m} / \mathrm{s}$ (Fig.3).

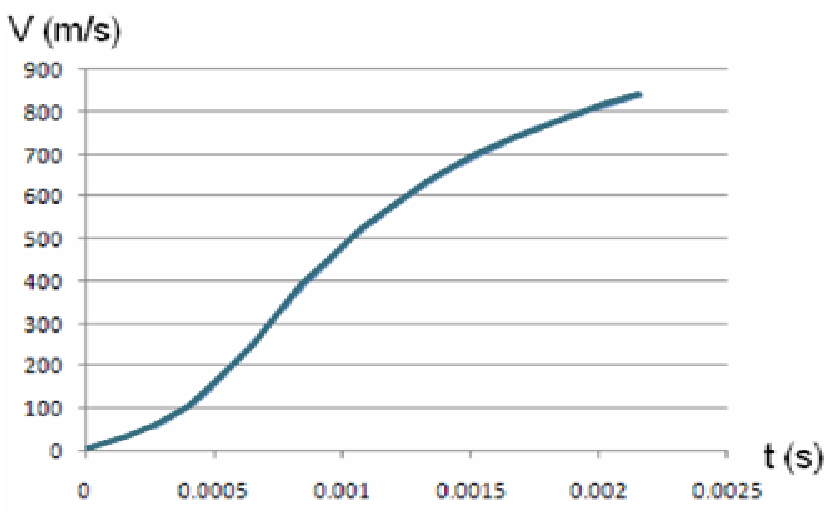

Figure 3. The optimal calculated velocity of the projectile in the barrel
When the bottom of the projectile passed over the orifice, gun powder gases enter the returnees chamber and act on the piston, creating a new force.

The pressure in the gas cylinder is calculated based on the model by E. L. Bravin [5]:

$$
p_{k}(t)=p_{\varphi} \cdot e^{-\frac{t}{b}} \cdot\left(1-e^{-\alpha \frac{t}{b}}\right)
$$

where: $p_{\varphi}$ - pressure of propellant gas in the barrel at the orifice for the evacuation of powder gases at the moment when the projectile passes the orifice, $t$-duration of action of gas on the piston, $\alpha$-coefficient of powder gases effect and $b$ - the ratio of unit impulse and pressure.

With all of the calculated values that exist in the expression (3), a function of pressure changes in the gas cylinder can be represented by:

$$
p_{k}=120 \cdot 10^{6} \cdot e^{-\frac{t}{0.001343}} \cdot\left(1-e^{-31.257 \cdot \frac{t}{0.001343}}\right) .
$$

The force of the bolt return spring acts after unlocking of bolt. Change of the force of the bolt return spring, depends on the bolt travelled distance $x_{1}$, obtained experimentally:

$$
F_{\text {op }}=157+396.08 \cdot x_{1} \text {. }
$$

For the purpose of realization, elastic connection of machine guns and gun-mount is the designed buffer. The experimentally determined spring force of the buffer is:

$$
F_{b f}=760+102142.9 \cdot x_{2} .
$$

where $x$ - displacement of machine gun.

Total recoil force in the phases is shown in Fig.4.

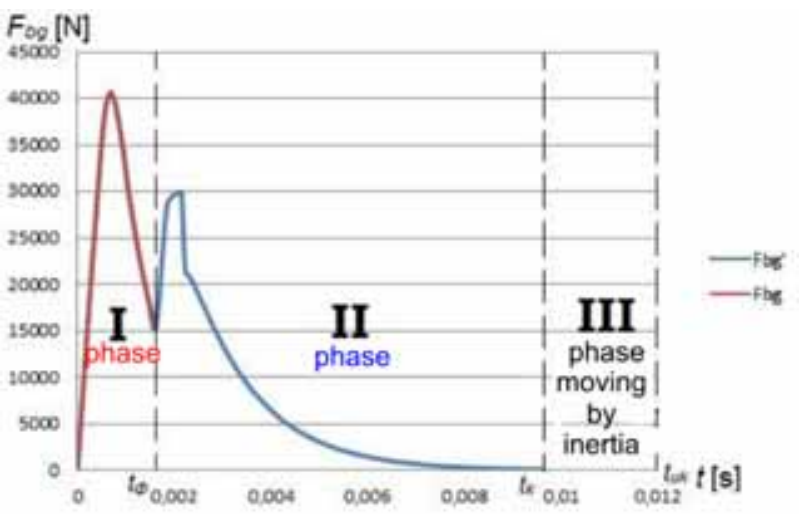

Figure 4. The recoil force change in phases

\section{Loading of designed gun-mount and bearing}

In order to calculate the forces acting on the bearing and on the basis of technical documentation from the factory "Zastava-Arms", by software CATIA V5 R18 model of machine gun assembly with a cradle and gun-mount is made (Fig.5). On the basis of this 3D model, the required positions of the barrel axis and the mass of projected cradle and the gun-mount are obtained [6].

The effect of force of gravity is entered as a negative acceleration acting on the whole body, while the effect of the recoil force entered as the effect of surface pressure (the bottom of the barrel). With adopted constrains, the lower surface of the bearing is fixed. Thanks to the simplified geometry, finite element mesh can be generated 
automatically. The final element is the shape of a tetrahedron. After completed analysis, required stresses and forces are reading. In Fig.6 field stress in MPs is represented in isometric view of the assembly.

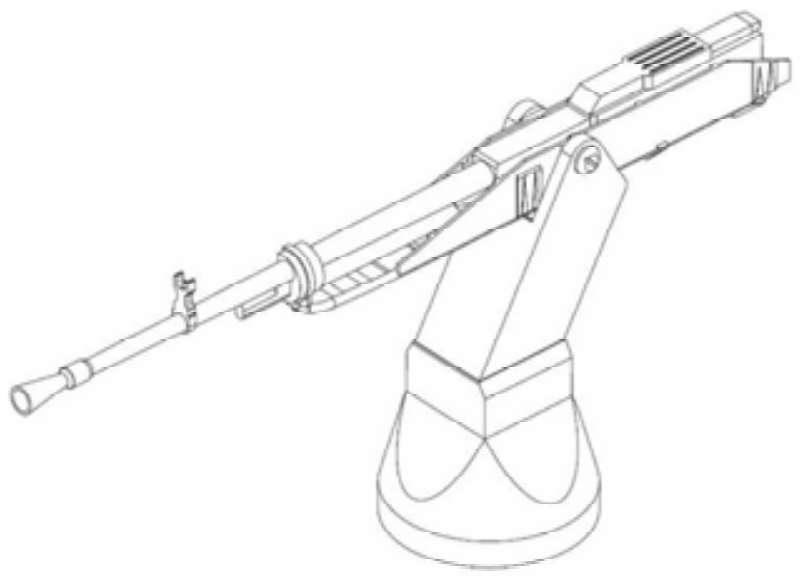

Figure 5. Isometric view of the assembly machine guns on the cradle and gun-mount

For the calculation of bearing it is necessary to know the intensity of the forces acting on the bearing. The stress of bearing is caused by recoil force and force of gravity. The simulated effects of the forces on the bearing in the direction of $\mathrm{x}, \mathrm{y}$ and $\mathrm{z}$ axes are shown in Fig. 7 .
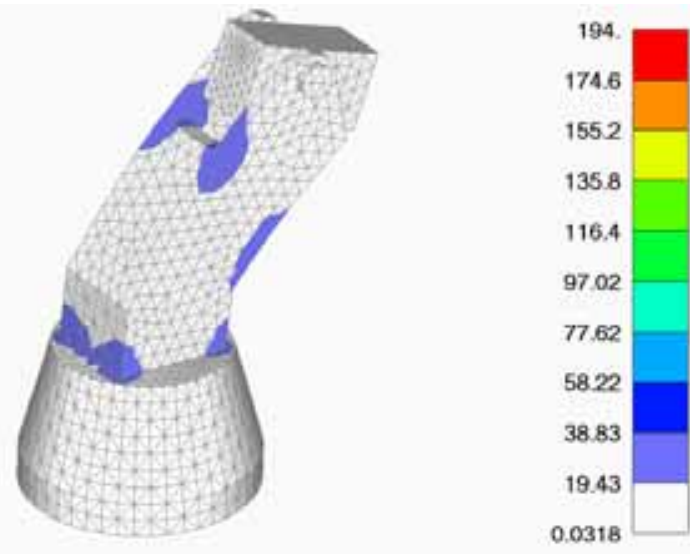

Figure 6. Field stress of gun-mount (MPa)

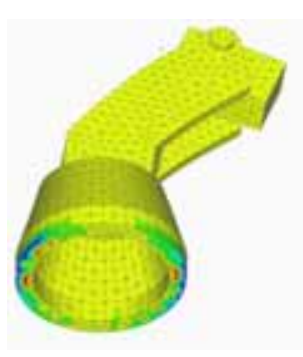

a) in the $\mathrm{x}$-direction
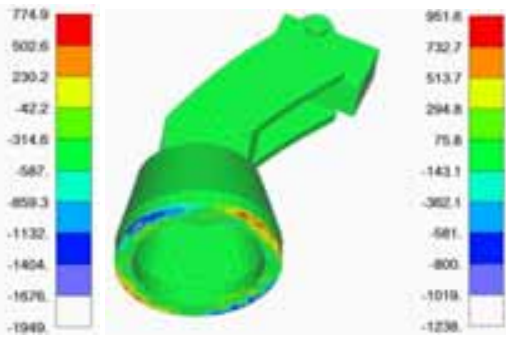

b) in the y-direction

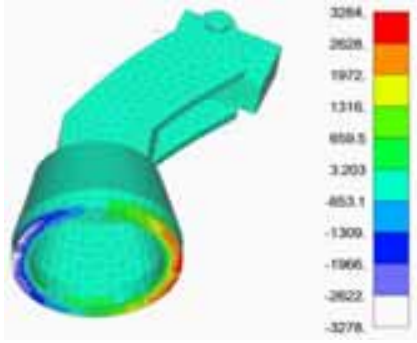

c) in the $z$-direction

Figure 7. Loading of bearing in MPa
By simulating loading machine gun assembly, cradle and gun-mount the following values of forces that load bearing are obtained: $F_{x}=1949 \mathrm{~N}, F_{y}=1238 \mathrm{~N}$ and $F_{z}=3284 \mathrm{~N}$ [6].

The calculation was performed taking into account the following assumptions $[6,7]$ :

- Mobile platform to which a machine gun is mounted is located on a horizontal surface;

- Distribution of additional vertical load on the ball of bearing is sinusoidal;

- Horizontal forces are distributed per balls as on radial ball bearings.

To determine the strain of roller tracks, it is necessary to determine the calculation load on the balls and the roller track, and then check the strain on the surface pressure.

Fig. 8 shows the forces that overload the rotating bearing in the vertical plane. Markings used in the figure are the following: $P_{k n}-$ recoil force, $F_{z}$ - vertical reaction of bearing, $\mathrm{G}$ - the total weight of the assembly machine gun and gunmount, $D$ - mean diameter of the bearing, $\rho_{G}, \Psi_{G}$ - polar coordinates of weight force, $\rho_{z}, \Psi_{z}$ - polar coordinates of vertical reaction [7].

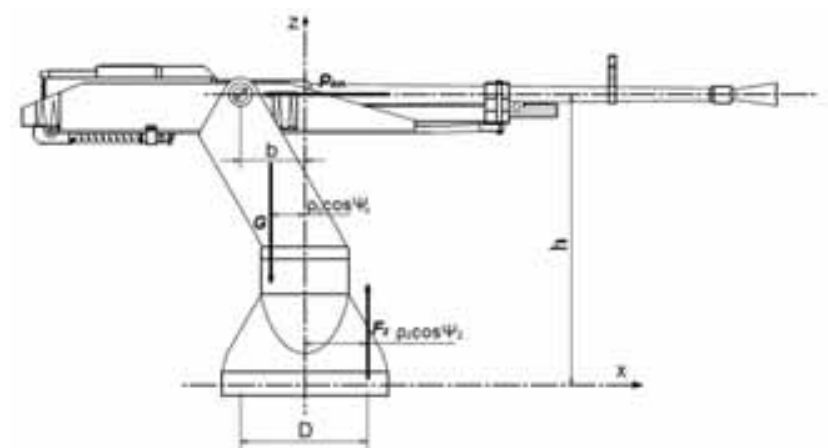

Figure 8. Scheme of rotating bearing loading in the vertical plane $x-z$

Vertical reaction of the bearing is obtained from the force equilibrium condition (Fig.8):

$$
\sum F_{Z}=F_{z}-G-F_{R} \sin \varphi=0 .
$$

where $\varphi$ - elevation angle, $F_{R}$ - resistance force of recoil. Force $F_{R}$ in this case is the maximum force of buffer spring $\left(F_{R}=2292.14 \mathrm{~N}\right)$. For minimal elevation angle $\varphi=0^{\circ}$, value of vertical reaction is minimal $F_{z \min }=1358.7 \mathrm{~N}$, whereas for a maximum elevation angle $\varphi=75^{\circ}$ the value of vertical reactions of bearing is maximal $F_{z \max }=3572.7 \mathrm{~N}$.

Polar coordinates of vertical reactions were determined from the momentum equation $\left(\sum M_{x}=0, \sum M_{y}=0\right)$, and geometric sizes are taken from CAD model $(b=135.7 \mathrm{~mm}, h$ $\left.=609.2 \mathrm{~mm}, \rho_{z}=28.747 \mathrm{~mm}\right)$.

Because $a=0$ (axis of machine guns is in the plane of the axis of rotation of bearing) and $y=0$ (force of gravity is in longitudinal plane of gun-mount), complete assembly is symmetrical in relation to the plane $\mathrm{x}-\mathrm{z}$, angle coordinate is $\Psi_{G}=0^{\circ}$. Then the polar coordinate $\rho_{z}$ is:

$$
\rho_{z}=\frac{G \rho_{G} \cos \psi_{G}+F_{R} b \sin \varphi-F_{R} h \cos \varphi}{G+F_{R} \sin \varphi} .
$$

For the most favourable, case momentum loading of bearing $\left(\varphi=0^{\circ}\right)$, according to Fig.8, we get that $\rho_{z}=-999 \mathrm{~mm}$. If $\left|\rho_{z}\right|>\mathrm{D} / 2$, the load tends to overturn assembly and roll-over protection must be used. In the specific case $(D=415 \mathrm{~mm})$ the obtained conclusion is that the 
structure is not stable in terms of rolling over, and it is necessary to use the roll-over protection.

The effect of the force on the bearing in the horizontal plane (x-y) is shown in Fig.9. Marks used in the figure are the following: $F_{h}$ - horizontal reaction of bearing, $F_{m k}$ - reaction mechanism for rotation, $\Psi_{h}$ - angle coordinate of horizontal reaction and $\Psi_{m k}$ - angle coordinate of reaction mechanism for rotation [7].

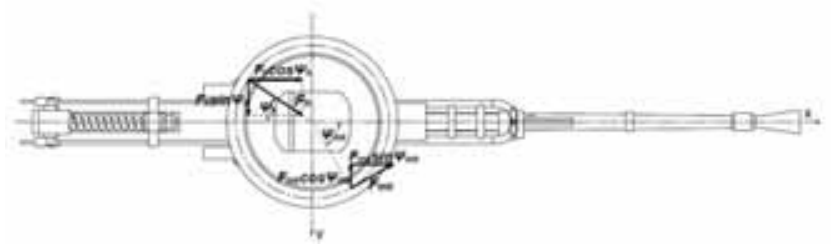

Figure 9. Scheme of rotating bearing loading in the horizontal plane $x-y$

Coordinates of resulting horizontal reactions $F_{h}$ are generally $\left(\mathrm{D} / 2, \Psi_{h}\right)$. Coordinates of reaction mechanism for gun-mount rotation $F_{m k}$ are designing determined $\left(\mathrm{a}=D / 2, \Psi_{m k}=45^{\circ}\right)$. Unknown parameters $\left(F_{h}, F_{m k}\right.$ and $\left.\Psi_{h}\right)$ are determined from equilibrium conditions:

$$
\begin{aligned}
& \sum F_{x}=0 \Rightarrow F_{m k} \sin \psi_{m k}+F_{h} \cos \psi_{h}-F_{R} \cos \varphi=0 \\
& \sum F_{y}=0 \Rightarrow F_{h} \sin \psi_{h}-F_{m k} \cos \psi_{m k}=0 \\
& \sum M_{z}=0 \Rightarrow F_{R} \cdot a \cdot \cos \varphi-F_{m k} \cdot \frac{D}{2}=0
\end{aligned}
$$

On the basis of system of equilibrium conditions equations (eq. 9) and condition that the axis of machine guns are at the geometric centre of the assembly, next parameters are obtained:

$$
\begin{aligned}
& F_{m k}=\frac{2 F_{R} a \cos \varphi}{D}=0 \\
& F_{h}=\mathrm{F}_{R} \cos \varphi \sqrt{1-\frac{4 a}{D} \sin \psi_{m k}+\frac{4 a^{2}}{D^{2}}}=2292.14 \mathrm{~N} \\
& \operatorname{tg} \psi_{h}=\frac{2 a \cos \psi_{m k}}{D\left(1-\frac{2 a}{D} \sin \psi_{m k}\right)} \Rightarrow \psi_{h}=0^{\circ}
\end{aligned}
$$

The effect of calculated forces and loading of bearing is shown in Fig. 10 [7].

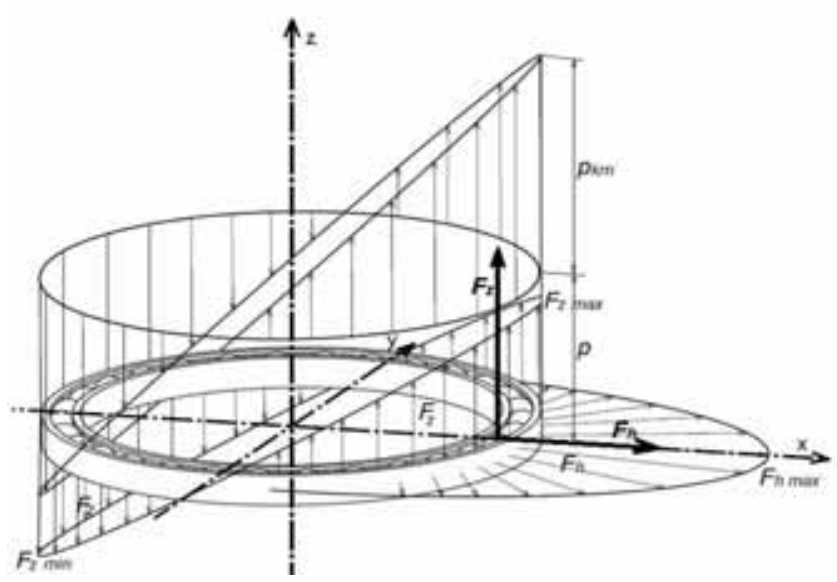

Figure 10. The loading of rotating bearing

\section{Conclusion}

In this paper, the results of two methodology for loadings calculation of heavy machine guns mount are compared.

In the paper was explained performed calculation of machine gun $12.7 \mathrm{~mm}$ force recoil, the impact of internal ballistic parameters to it is discussed, as well as its effect on the assembly of the machine guns, the cradle and the gun-mount.

Based on the design parameters of the machine guns, a gunmount was designed together with the cradle and the rotating bearing. Modelling was performed in the software package CATIA V5R18 with the condition of minimum recoil force and minimum allowable mass of gun-mount. Since the selected machine gun is gas operated, apart from the basic force of pressure of powder gases at the head of a bolt which causes recoil of machine gun, the force of pressure of powder gases on the forehead of the piston in the gas cylinder should be taken into account. All other forces that occur during firing, are the resistance forces of recoil and have the opposite direction.

By internal ballistic calculation the maximum pressure in the barrel of $12.7 \mathrm{~mm}$ machine gun which obtained is $p_{m}=328.98$ $\mathrm{MPa}$. By varying appropriate ballistic parameters of powder, an optimal solution is obtained $\left(p_{m}=308.25 \mathrm{MPa}\right)$. This solution provided minimal recoil force, with the least possible disruption of output values as initial velocity of the projectile.

With such obtained recoil force, the calculation of load and forces acting on the rotating bearing was made. The calculation is done in two ways. The first used the method of finite elements by program FEMAP. The most loaded parts of the gun-mount are under stress from 19.43 to $38.83 \mathrm{MPa}$.

The second method is based on calculation of bearing components load from the equilibrium condition.

By comparing the values of reaction forces of rotating bearing, obtained by using these two methods, it can be seen that they are very close and that in the vertical direction there are differences by about $8 \%$, and in the horizontal direction by about $1 \%$.

Regardless of the way of calculation of the reaction forces of rotating bearing, they can further be used for the calculation of the elements of a machine gun automatic control, as well as for calculations of mobile platform loading during firing.

\section{Acknowledgment}

This work is part of the project III47029 in 2016, funded by the Ministry of Education, Science and Technological Development of Republic of Serbia.

\section{References}

[1] RISTIC,Z.: Mechanic of Artillery Weapons, Odbrana Media Center, Belgrade, Serbia, 2016. (in print)

[2] BABAK,F.K.: Machine guns, Polygon, Sankt Petersburg, Russia, 2005.

[3] CVETKOVIC,M.: Internal Ballistic, Military Academy, Belgrade, Serbia, 1998.

[4] TANCIC,LJ.: Internal Ballistics Design, Odbrana Media Center, Belgrade, Serbia, 2014.

[5] PETROVIC,M.: Mechanics of Automatic Weapons, Odbrana Media Center, Belgrade, Serbiia, 2007.

[6] CHOBITOK,V.A.: Construction and Calculation of Tanks and Infantry Combat Vehicles. (In Russian), Voennoe izdatelstvo, Moscow, 1984.

[7] JOVANOVIC,D.: Integration of machine gun 12.7 millimeters on mobile platform-master thesis, Faculty of Engineering, Kragujevac, Serbia, 2015. 


\title{
Analiza opterećenja postolja integrisanog mitraljeza kalibra $12.7 \mathrm{~mm}$
}

\begin{abstract}
U radu je opisan problem integracije mitraljeza kalibra $12,7 \mathrm{~mm}$ na mobilnu platformu. Na osnovu dimenzija mitraljeza urađeno je modeliranje postolja mitraljeza sa kolevkom. Izrađeni model je popuno funkcionalan i realan. Na osnovu optimizovanih unutrašnje balističkih parametara izvršen je proračun sile trzanja i opterećenja postolja i obrtnog ležaja. Proračun opterećenja ležaja vršen je na dva načina. U prvom slučaju primenjena je metoda konačnih elemenata i korišćen softverski paket FEMAP. Druga metoda bazira se na izračunavanju komponenata otpora ležaja iz uslova ravnoteže. Na kraju je izvršena komparativna analiza podataka dobijenih po ove dve metode.
\end{abstract}

Ključne reči: mitraljez, kalibar 12.7 mm, sila trzanja, postolje, ležajevi, proračun opterećenja, analiza napona, metoda konačnih elemenata, integrisano oružje.

\section{Анализ напряжений лафета интегрированого пулемёта калибра 12,7 мм}

\begin{abstract}
В этой статье описывается проблема интеграции пулемётов калибра 12,7 мм на мобильную платформу. Исходя из размеров пулемёта смоделирована подставка пулемёта на люльке. Сделанная модель является полностью функциональной и реалистичной. На основе оптимизированных внутренних баллистических параметров проводится расчёт силы отдачи и нагрузки базы и вращающегося подшипника. Расчёт нагрузки подшипника был проведён двумя способами. В первом случае применяется метод конечных элементов и был использован программный пакет FEMAР. Второй метод основан на расчёте сопротивления подшипниковых компонентов из состояния равновесия. В конце изготовлен сравнительный анализ данных, полученных из этих двух методов.
\end{abstract}

Ключевые слова: пулемёт, калибр 12,7 мм, сила отдачи, постамент, подшипники, расчёты нагрузки, анализ напряжений, анализ методом конечных элементов, интегрированное оружие.

\section{Analyse de la charge d'affût de la mitrailleuse intégrée de 12,7 mm}

\begin{abstract}
Dans ce papier on a décrit le problème de l'intégration de la mitrailleuse de $\mathbf{1 2 , 7} \mathrm{mm}$ sur la plate-forme mobile. A la base des dimensions de la mitrailleuse on a fait la modélisation de l'affût de mitrailleuse avec le berceau . Le modèle réalisé est entièrement fonctionnel et réel. Le calcul de la force de recul et de la charge d'affût et de roulement a été fait à la base des paramètres de la balistique intérieure optimisés. Le calcul de la charge de roulement a été effectué à deux façons. En premier cas on a utilisé la méthode des éléments finis et on a appliqué le logiciel FEMAP. La seconde méthode est basée sur le calcul des composantes de résistance des roulements à partir des conditions de l'équilibre. A la fin une analyse comparative a été faite pour les données obtenues par ces deux méthodes citées.
\end{abstract}

Mots clés: mitrailleuse, calibre de 12,7 $\mathrm{mm}$, force de recul, affût, roulement, calcul de charge, analyse de tension, méthode des éléments finis, arme intégrée. 